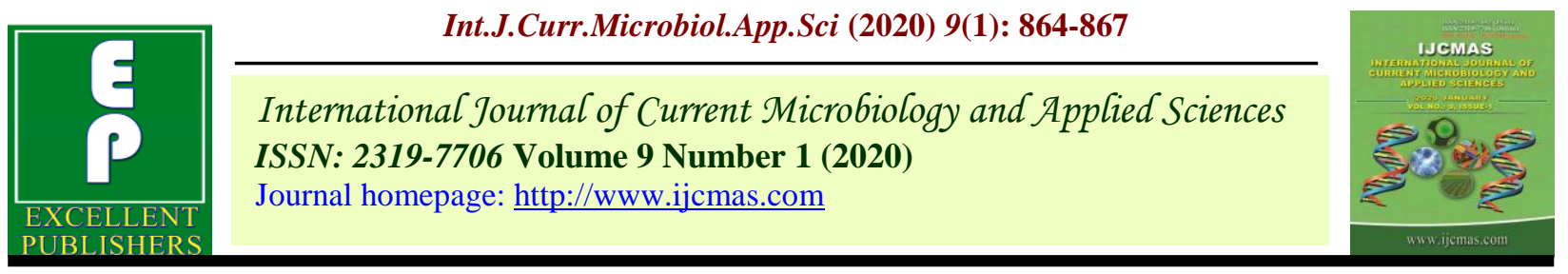

Original Research Article

https://doi.org/10.20546/ijcmas.2020.901.096

\title{
Trend Analysis on Number of Rainy Days and Seasonal Rainfall over the North East Monsoon of Pudukkottai District, India
}

\author{
N. Kowshika* and M. R. Latha \\ ICAR-KVK Vamban, Pudukkottai, India \\ *Corresponding author
}

\begin{tabular}{|l|}
\hline Ke y w o r d s \\
Rainfall, Rainy \\
days, Trend analysis \\
\hline Article Info \\
\hline $\begin{array}{l}\text { Accepted: } \\
\text { 15 December } 2019 \\
\text { Available Online: } \\
\text { 20 January } 2020\end{array}$ \\
\hline
\end{tabular}

\section{A B S T R A C T}

Climate change and its influence on rainfall, accounts important for agricultural production. All farm activities are indeed focused based on the rainfall amount and its distribution over the cropping season. The trend analysis on Northeast monsoon rainfall amount and distribution of the rainfall in number of rainy days was conducted for Pudukkottai district to understand climatological performance of rainfall. With a study period of 35 years the analysis was able to conclude that there had been 7 excess rainfall years, 11 deficit years and 17 normal rainfall years and having an increasing trend. Contradictorily, the number rainy days faced a decreasing trend that could result intense rainfall distribution. Crop planning and management activities could be framed based on the rainfall distribution.

\section{Introduction}

Rainfall is considered as the life line irrigation source of all living forms especially in agricultural sector. Crop selection, cropping pattern, crop performance, crop productivity etc. are completely dependent on rainfall, particularly for the rainfed regions (Auffhammer et al., 2012). The rainfall amount is no longer the only parameter to decide crop performance, the intensity and number of rainy days are the major role players in the present scenario of rapid climate change. Though Tamilnadu experiences rainfall in both the monsoon seasons, North East Monsoon holds in the majority, where Pudukkottai district is favoured through 48 per cent of the annual rainfall in this season (Sumathi et al., 2011). Analysis on the distribution of rainfall would help in crop planning for the district which is partly a delta area and other crops are evenly occupied. Rainfall analysis holds a significant role in a major rice producing region like Pudukkottai (Kasula Sekhara, 2019). Trend analysis on the seasonal rainfall and its distribution as number of rainy days for Pudukkottai district was done to understand the climatological influence of North East Monsoon rainfall over the district. 


\section{Materials and Methods}

The trend analysis on number of rainy days and the North East Monsoon rainfall of Pudukkottai district was performed for a study period of 35 years (1979-2013). The rainfall data was obtained from Climate Forecast System Reanalysis (CFSR) data from which the seasonal rainfall and number of rainy days were processed in Weathercock software. The trend on both the parameters and rainfall deviation were analysed using Microsoft excel. The category of rainfall deviation was based on the IMD classification (imd.gov.in):

\begin{tabular}{|l|l|}
\hline Rainfall Deviation & Classification \\
\hline$>19$ per cent & Excess \\
\hline+19 to -19 per cent & Normal \\
\hline Less than -19 per cent & Deficit \\
\hline
\end{tabular}

\section{Results and Discussion}

The analysis on number of rainy days revealed a slight decreasing trend for the study period whereas the rainfall amount showed an increasing trend for the study period (Figure 1). Among the 35 years of study 7 years have been excess rainfall, 11 years of rainfall deficit and 17 years of normal rainfall conditions for North East Monsoon in Pudukkottai district (Table 1).

The decrease in number of rainy days and increase in the rainfall amount would result in more intense rainfall in the short span of available rainy days. This would possibly result in crop damage and soil erosion leading to adverse effects on crop productivity and soil health. Hence, proper measures on rain harvesting and erosion management is necessary. Moreover, the number of rainy days will impact on length of growing period.

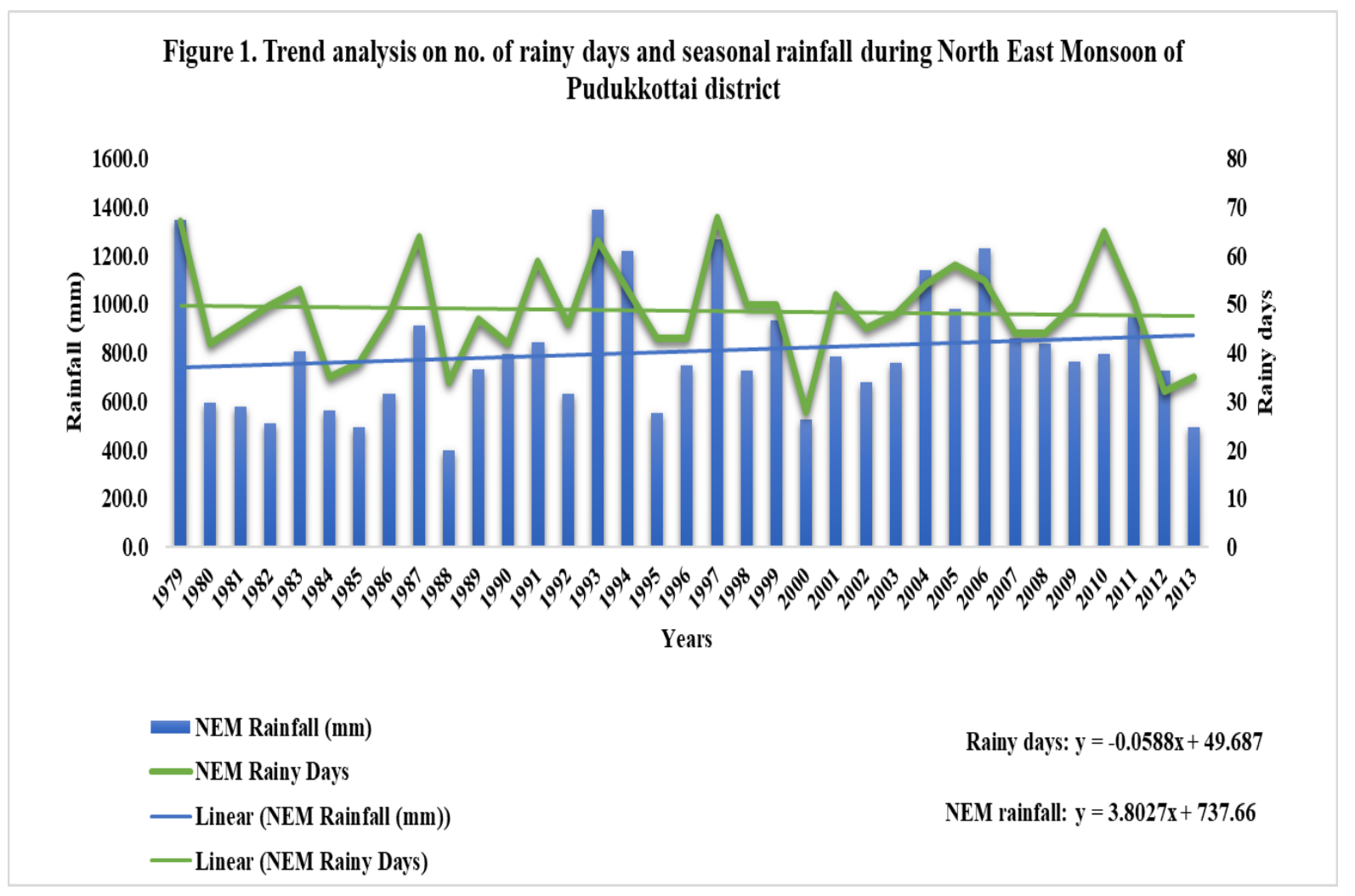


Table.1 Number of rainy days, rainfall amount and rainfall classification of Northeast monsoon (1979-2014) for Pudukkottai district

\begin{tabular}{|c|c|c|c|}
\hline Year & NEM Rainy Days & NEM Rainfall (mm) & Rainfall classification \\
\hline 1979 & 67 & 1348.5 & Excess \\
\hline 1980 & 42 & 595.6 & Deficit \\
\hline 1981 & 46 & 580.5 & Deficit \\
\hline 1982 & 50 & 510.1 & Deficit \\
\hline 1983 & 53 & 806.1 & Normal \\
\hline 1984 & 35 & 564.9 & Deficit \\
\hline 1985 & 38 & 491.9 & Deficit \\
\hline 1986 & 48 & 630.2 & Deficit \\
\hline 1987 & 64 & 912.2 & Normal \\
\hline 1988 & 34 & 397.6 & Deficit \\
\hline 1989 & 47 & 734.0 & Normal \\
\hline 1990 & 42 & 794.5 & Normal \\
\hline 1991 & 59 & 842.5 & Normal \\
\hline 1992 & 46 & 633.5 & Deficit \\
\hline 1993 & 63 & 1392.1 & Excess \\
\hline 1994 & 53 & 1218.8 & Excess \\
\hline 1995 & 43 & 551.7 & Deficit \\
\hline 1996 & 43 & 746.5 & Normal \\
\hline 1997 & 68 & 1270.2 & Excess \\
\hline 1998 & 50 & 726.9 & Normal \\
\hline 1999 & 50 & 935.6 & Normal \\
\hline 2000 & 28 & 526.6 & Deficit \\
\hline 2001 & 52 & 785.4 & Normal \\
\hline 2002 & 45 & 681.5 & Normal \\
\hline 2003 & 48 & 756.7 & Normal \\
\hline 2004 & 54 & 1142.5 & Excess \\
\hline 2005 & 58 & 979.1 & Excess \\
\hline 2006 & 55 & 1232.0 & Excess \\
\hline 2007 & 44 & 860.0 & Normal \\
\hline 2008 & 44 & 837.3 & Normal \\
\hline 2009 & 50 & 763.8 & Normal \\
\hline 2010 & 65 & 793.6 & Normal \\
\hline 2011 & 51 & 949.3 & Normal \\
\hline 2012 & 32 & 726.7 & Normal \\
\hline 2013 & 35 & 495.3 & Deficit \\
\hline
\end{tabular}

*NEM - North East Monsoon

The trend analysis on North east monsoonal rainfall and number of rainy days was able to conclude that the seasonal rainfall amount is increasing while the number of rainy days is decreasing which would impact in more intense rainfall behaviour. Suitable crops and varieties that would cope with the available rainfall and rainy days are necessary for the future. The knowledge about changing seasonal rainfall and choosing suitable crop, would benefit the farmers in the aspect of weather based farming to protect the crop and 
increase the yield. Similar results were observed for trend analysis on annual rainfall in Pudukkottai district (Kowshika et al., 2019)

\section{Acknowledgment}

The guidance and support of Dr. M. R. Latha, Programme Coordinator, ICAR-KVK, Vamban, Pudukkottai and Tamil Nadu Agricultural University is gratefully acknowledged.

\section{References}

Auffhammer M., Ramanathan V., Vincent J.R. 2012. Climate change, the monsoon, and rice yield in India. Climatic Change. 111, 411-424. http://imd.gov.in/section/nhac/termglossary.p df
Kasula Sekhara. 2019.Trends in Area, Production and Productivity of Paddy Crop: an Overview. International Journal of Humanities and Social Science Invention, 8 (1): 50-58

Kowshika, N., Latha, M. R., and Dheebakaran, Ga. 2019.Trend analysis of annual rainfall and rice production in Pudukkottai district of Tamilnadu. In Proceedings of National Conference on Climate Smart Agriculture for Livelihood Security: Challenges and Opportunities, AC\&RI, Tiruchirappalli, Tamilnadu, India. p: 337

Sumathi, M., Kumarasamy, K., Thitagarajan, M., and Punithavathi, J. 2011. Astudy on the temperature and rainfall conditions of Pudukkottai District, Taminadu, India. International Journal of Development Research. 1 (3): 22-26

\section{How to cite this article:}

Kowshika, N. and Latha, M. R. 2020. Trend Analysis on Number of Rainy Days and Seasonal Rainfall over the North East Monsoon of Pudukkottai District, India. Int.J.Curr.Microbiol.App.Sci. 9(01): 864-867. doi: https://doi.org/10.20546/ijcmas.2020.901.096 